\title{
Ancient Festivals and Their Cultural Contribution to Society
}

\author{
Ioanna-Soultana Kotsori \\ University of Peloponnese, Kalamata, GREECE \\ Faculty of Humanities and Cultural Studies
}

Received 25 August 2019 • Revised 5 October 2019 • Accepted 17 October 2019

\begin{abstract}
Festivals are cultural and social events involving a multitude of events and are usually held by a crowd of people in a community. We have written testimonies of the existence of holidays in the ancient Egyptian, the Ancient Greece, and the Ancient Rome. These celebrations were mostly religious in nature, and were rural or devoted to the patron gods, or local heroes. In Ancient Athens, each celebration consists of the procession, the sacrifice, the hymns, the sacrificial meal and the races that can be athletic (nude), equestrian and musician. In addition to the festivities that exclusively concerned citizens of a particular city excluding any other Greeks, there were also Pan-Hellenic cults and races, common and open to the entire Greek community. Organizing local festivals enhances local artistic development. In particular, it contributes to the production and promotion of various forms of artistic expression but also to the exploitation of cultural potential.

Keywords: festival, celebrations, PanHellenic games, cultural management.
\end{abstract}

\section{Introduction}

Since antiquity, in every society, regardless of place and time, there have been festivals centered on religious faith, peculiar local culture, and everyday life. The celebration of exceptional events, or of worship and honor, to deity, hero, and prominent persons are ancient. In ancient Greece mainly and later in Rome the festivals were widely celebrated and associated with the organization of processions, sports or artistic competitions, theatrical performances, etc.

These festivals were the beginning of the festivals. Festivals are cultural and social events involving a multitude of events and are usually held by a crowd of people in a community. Festivals are a great source of income and tourism locally and internationally. Many organizers are trying to demonstrate the contribution of festivals to local development using mainly economic analysis and various impact assessment methods.

What is the special relationship between the festival and the society that organizes or hosts such an event? Is it just a simple record of participant and sponsorship or earnings data? As Getz says, this process requires further analysis and commentary (Getz, 1991: 5).

Consequences should be sought at the individual and social level, as the event was not always addressed to the local residents themselves. Its most important role is to promote art and culture as a public good that is accessible to all. The attractive cultural environment creates

(C) Authors. Terms and conditions of Creative Commons Attribution 4.0 International (CC BY 4.0) apply. Correspondence: Ioanna-Soultana Kotsori, University of Peloponnese, Faculty of Humanities and Cultural Studies, Department of History, Archaeology and Cultural Resources Management, Kalamata, GREECE. E-mail: ioannakotsori@gmail.com. 
activated citizens and develops communication between them. In conclusion, a city without culture cannot exist, and cultural institutions concern all citizens as they constitute its cultural present and future. In modern Greece, the first official festival organization was the Athens Festival, with the Epidaurus opening in 1954 at the ancient theater of Epidaurus.

\section{Ancient Egypt}

As early as $2500 \mathrm{BC}$, we have written testimonies of the existence of holidays in the ancient Egyptian calendar. Opeth's celebration in ancient Egypt, or "Opeth's beautiful feast", was one of the most important annual festivals in the greater Thebes. The word "opeth" means "secret chamber" and refers to the private and secret rooms adjoining the sacred sanctuary of the god Amon of Luxor (Wilkinson, 2000: 171). In the inner chamber of the temple of Amenhotep III, Opeth's celebration was essentially a celebration of the royal birthday and through special rituals, during this time, the divine kingdom is rejuvenated and the royal right to power is reaffirmed as the power and authority of the god Amon (who in the New Kingdom was the official state god) transferred to his living son on earth, Pharaoh (Bell, 1997: 174).

Twenty-seven days were celebrated during the twenty-first dynasty, the boat of the god being carried on the shoulders by the priests of the temple throughout the voyage. The procession was accompanied by priests, officials, soldiers, anecdotes, acrobat dancers, drummers, musicians, the king's chariots and the king himself. Benches with food, drinks and offerings spread across the street leading from the river procession to the temple.

But most of all those who enjoyed the celebration were ordinary citizens. It is recorded that in an Opeth's celebration of the twelfth century BC temple officials distributed 11,341 loaves of bread and 385 jars of beer to the people (Brier, 1999: 75, 112). Paradoxically, this procession still continues today, on a different religious background. Every year at the "Feast of the Saints" a boat is transported from the Abu-el-Haggag mosque through the streets of Luxor.

\section{Hellas}

The celebrations of our ancient ancestors were mostly religious in nature, and were rural (Dionysian, Lenaean, Antistiria), or devoted to the patron gods, or local heroes, and our ancestors were considered by them scholars as one of the most revered people in the world. These celebrations were not unique, but they are considered to be the largest and most important of the year, during which almost the entire state took part, and there have been reports of temporary cessation of war operations for warriors to attend celebrations.

During large gatherings called "festivals", activities of all kinds were held around the sanctuary - real bargains set up because of the overcrowding of people. It is also not unusual, in spite of the inviolability of the sacred site, to become a battlefield. A famous scene, reported by Xenophon, describes a battle between the Illyrians and the Arcadians at the Sanctuary of Olympia: they fly arrows from the propylons, even from the great temple, erect barricades and climb the roof of the temple waiting for the opponent. Therefore, the sanctuaries are, as we see, living spaces (Orrieux, 1995: 300).

\subsection{Ancient Sparta}

Hyacinthia was a famous three-day Laconic celebration that coincided with the last days of May, or the first of June in honor of Hyacinth at first, and after Apollo, at Amycles, five kilometers south of Sparta near Eurotia. Their participation in the celebration of the Yakinthians was considered by the Spartans and the Amyclians a fundamental religious duty. Xenophon, in 
the Hellenics (IV, 5, 11), reports that the Spartans interrupted their campaigns in order to be able to return to Laconia so as to participate. ${ }^{1}$

Carnea was the second major Laconic holiday that lasted nine days in Sparta, the local month of Carnegie in August and probably sometime in the first days of September, depending on the Full Moon. In the beginning the feast was dedicated to a local god named Karnos, it was a ram and was considered a patron of fertility and fruit harvesting. The great importance attached to the festival and its month is shown in several instances. It was responsible for the delay which prevented the Spartans from assisting the Athenians at the battle of Marathon (Herodotus, VI. 106), and for the dispatch of a small advance guard under Leonidas to hold Thermopylae instead of the main army (Herodotus, VII. 206).

Gymnopaedia in ancient Sparta was a yearly celebration during which naked youths displayed their athletic and martial skills through the medium of war dancing. The custom was introduced in 668 BC, (Cartledge, 2003: 102) concurrently with the introduction of naked athletics. The festival, dedicated to Apollo, was celebrated every year in the summertime with gymnastic contests (Pausanias, Desrciption of Ancient Greece, 3.11.7). The festival lasted for several, perhaps for ten days. The Gymnopaedia was a polis event and religious festival, which involved the entire society, including girls and women.

\subsection{Ancient Athens}

Most celebrations were dedicated to Athena. Each celebration consists of the procession, the sacrifice, the hymns, the sacrificial meal, and the races that can be athletic (nude), equestrian and musician. Panathenaia was celebrated on 28 July every four years and lasted for twelve days. The competitions for which this festival came to be known were only part of a much larger religious occasion - the Great Panathenea itself. These ritual observances consisted of numerous sacrifices to Athena (the name-sake of the event and patron deity to the hosts of the event - Athens), as well as Poseidon and others.

The Panathenaic festival was formed in order to honor the goddess Athena who had become the patron of Athens after having a competition with the god Poseidon where they were to win the favor of the Athenian people by offering the people gifts. The festival would also bring unity among the people of Athens. A sister-event to the Great Panathenaia was held every year the Lesser Panathenaia, which was 3-4 days shorter in celebration. The competitions were the most prestigious games for the citizens of Athens, but not as important as the Olympic Games or the other PanHellenic Games. The Panathenaic Games held contests in a number of musical, athletic, and equestrian events. Due to the fact that there were so many contests held, the games usually lasted a little over a week (Pausanias, Desrciption of Ancient Greece, 1, 27, 3).

A number of festivals were dedicated to the god Dionysus. The Dionysian celebration cycle was most likely linked to the ceremonies of the vegetation and life cycle. For the Greeks of classical times, Dionysus was not only the god of wine. The main feasts were the Dionysians, the Lenaia, and finally the Antestiria, and some other great feasts are mediated.

Lenaia was an annual Athenian festival with a dramatic competition. It was one of the lesser festivals of Athens and Ionia in ancient Greece. The Lenaia took place in Athens in January. The festival was in honor of Dionysus. The audiences for the Lenaia were usually limited to the local population, since travel by sea at that time of year was considered unsafe. At first, the festival held dramatic competitions only for comedy, but in 432 BCE a tragic contest was introduced. Many of Aristophanes' plays were first performed there, such as Knights (Brockett, 2003: 20).

${ }^{1}$ For further information: http://www.hellenicaworld.com/Greece/WS/en/Hyacinthia.html. 
Thesmophoria took place over three days, from the eleventh to the thirteenth of October (Dillon, 2002: 110) and was the time of the Greek year when seeds were sown. The Thesmophoria may have taken place in this month in other cities, though in some places - for instance Delos and Thebes - the festival seems to have taken place in the summer, and been associated with the harvest, instead. In other places the festival lasted for longer - in Syracuse, Sicily, the Thesmophoria was a ten-day long event. The most extensive sources on the festival are a comment in a scholion on Lucian, explaining the festival, and Aristophanes' play Thesmophoriazusae, which parodies the festival (Dillon, 2002: 111).

\subsection{PanHellenic games}

In addition to the festivities that exclusively concerned citizens of a particular city excluding any other Greeks, there were also PanHellenic cults and races, common and open to the entire Greek community, such as those expressed at the famous Olympia or Delphi sanctuaries (Orrieux, 1995: 290).

Hellenic struggles first emerge as a PanHellenic movement, based on the need for man to interrupt wars, even for short periods of time, and to refer to the fundamental bonds that bind him to his fellow man (Miller, 1989: 15). This need, transformed into sporting and religious celebrations, has transferred human competition from the battlefields to the athletic arena (Miller, 1989: 11). Thus, for a certain period every year a PanHellenic truce came into force.

The truce had become a Pan-Hellenic experience and the purpose of its conclusion was the national interest, the realization of the unity instead of the destructive divide. That is, before the date of each race a sacred truce is declared so that pilgrims can visit the temples without the risk of retaliation (Orrieux, 1995: 303).

Of the many fights that took place throughout the ancient Greek world, four were those that came out of narrow local boundaries and became PanHellenic religious and athletic festivals because they developed within powerful religious centers and states with politically flourishing and militant areas. As early as $776 \mathrm{BC}$ was born the Olympic idea in honor of Zeus, whose power continues to move humanity even today.

After Olympia, other great PanHellenic sanctuaries of Delphi followed in 586 BC. In honor of Apollo, the Isthmus in 580 BC. In honor of Neptune and Nemea in 573 BC in honor of Zeus. Since then the races have been regular throughout the ancient times. These struggles were called "common" and "sacred" and earned the appreciation and recognition of the entire ancient Greek world. The winners, crowned with branches of trees or plants, after returning to their homeland, entered the city from a part of the wall that their compatriots had demolished, thinking that when they had such heroes, they did not need walls. ${ }^{2}$

The institutionalization of the four PanHellenic struggles in antiquity helped to forge the unity of Hellenism. The great PanHellenic struggles caused the interest and participation of all Greeks. They were an attraction for a multitude of athletes who wanted to leave eternal glory through their sporting achievements, but also for a large number of spectators who wanted to watch the purest form of sports competition, applaud athletic excellence and have fun (Orrieux, 1995: 305).

The races also played a social role as people came closer, reinforcing their national identity and unity, and reinforced the sense of "belonging". If you look at the list of Olympians,

${ }^{2}$ For further information: http://www.hellenicaworld.com/Greece/Ancient/en/Olympic.html. 
they will see their wide spectrum of origin and understand the importance of the competition and sympathy of all these Greeks for consolidating their national consciousness.

\section{The Roman era}

During the Roman Empire, the Dionysian and Bacchian associations flourished. For many centuries, Dionysian, Orphic, and Eusebian ideas were merged with (Kennedy, 1972: 86). In the following centuries, the religious and social life of the Roman Empire holds an equally important place in celebrations and public holidays, which over the years have become abundant (Dimou, 2016: 14).

In Latin there were two conditions for festive events: festum, as a public holiday, cheerfulness, feast and feria, which means abstaining from work in honor of the gods. Both terms were used in the plural, festa and feria, which indicates that already at that time festivals lasted many days and included many events (Falassi, 1987: 1-2).

Saturnalia was an ancient Roman festival in honor of the god Saturn, held on 17 December of the Julian calendar and later expanded with festivities through to 23 December. The holiday was celebrated with a sacrifice at the Temple of Saturn, in the Roman Forum, and a public banquet, followed by private gift-giving, continual partying, and a carnival atmosphere that overturned Roman social norms: gambling was permitted, and masters provided table service for their slaves (Parker, 2011: 211). Saturnalia was the Roman equivalent to the earlier Greek holiday of Kronia, which was celebrated during the Attic month of Hekatombaion in late midsummer (Bremmer, 2008: 82). Unlike several Roman religious festivals which were particular to cult sites in the city, the prolonged seasonal celebration of Saturnalia at home could be held anywhere in the Empire. Saturnalia continued as a secular celebration long after it was removed from the official calendar (Aulus Gellius 18.2.1).

Lupercalia was an ancient, possibly pre-Roman pastoral annual festival (Lupercalia: Encyclopedia Britannica, $17-11^{\text {th }}$ ed. - 126.) observed in the city of Rome between 13 and 15 February, to avert evil spirits and purify the city, releasing health and fertility. It was said that it was originally a pastoral feast, as Lupercus was a shepherd's patron and associated with Roman's upbringing and breastfeeding. At the Lupercal altar, a male goat (or goats) and a dog were sacrificed.

After the sacrifice, a gathering was organized where plenty of wine flowed. Over the years it lost its glamor as the Romans were not a shepherd's race, but the celebration continued in remembrance of the founders of Rome and was a pure folk amusement that satisfied the beastly instincts of its faithful.

\section{Cultural management}

In the ancient Greek world, about two and a half thousand years ago, institutions, traditions and ideas developed that still form the basis of modern culture. Through this effort, various political systems and institutions were born and developed in the Greek city-states.

Cultural policy is defined by UNESCO as a set of social practices, conscious and calibrated, interventions or non-interventions aimed at satisfying certain cultural needs by making the most of all the material and human resources that a given society has, in a certain moment. And yet this policy must set some criteria for cultural development and link culture with personality formation and socio-economic development (UNESCO, 1969: 8).

Festivals play an important role in local communities, offer opportunities for fun and leisure, stigmatize memory and contribute to the local economy (Long, 1990: 10-14). The 
organization of cultural activities of a festival aims to create an attractive cultural image of the city. Cities during the festival promote local identity and culture. Festivals also help to reinforce the social dimension of the city.

According to Getz (Getz, 2005: 20-30), festivals exert social and cultural influence on the participants as well as the wider community. Influences are about sharing experiences, discovering new possibilities and stimulating the imagination. The attraction of visitors as well as artists and professionals of the area enhances the economy of the area. Everyone in the area is spending money, stimulating the local market and empowering local businesses. Businesses are often advertised for free through the postings of visitors' experiences on social networks.

In addition, the tourist development of the place is being enhanced. Tourism enhances pride and creates cultural identity, cohesion, exchange of ideas and increased knowledge about the culture of an area (Besculides et al., 2002: 303). Local government integrates festivals with local development efforts recognizing their potential as tourist catalysts. However, festivals, in addition to local development and strengthening local identity, can also have some negative effects. Some of these may be the annoyance of residents from the overwhelming number of visitors, excessive alcohol consumption, road closures, traffic jams, difficulty finding parking, etc. In summary, we could say that festivals are part of the cultural work of municipalities.

Organizing local festivals enhances local artistic development. In particular, it contributes to the production and promotion of various forms of artistic expression but also to the exploitation of cultural potential. In addition, it can highlight the local color of an area, improve the image of a city and create the conditions needed for its multifaceted development (to be an attraction for visitors, new residents, new businesses, etc.) in the modern competitive environment (Gkagka, 2018: 31).

\section{Conclusions}

The written testimonies revealed the existence of festivals in the ancient Egyptian, the Ancient Greece and the Ancient Rome, which served mostly religious purposes. These celebrations had or local character or global interest, so were common and open to the entire community. In ancient Greece mainly and later in Rome, the festivals were widely celebrated and associated with the organization of processions, sports or artistic competitions, and theatrical performances.

Festivals are a great source of income and tourism locally and internationally. Many organizers are trying to demonstrate the contribution of festivals to local development using mainly economic analysis and various impact assessment methods. The festival and the society that organizes or hosts such an event have to collaborate for a successful result.

\section{Acknowledgements}

This research did not receive any specific grant from funding agencies in the public commercial, or not-for-profit sectors.

The author declares no competing interests. 


\section{References}

Bell, L. (1997). The new kingdom 'divine' temple: The example of Luxor. In: B. E. Shafer (ed.), Temples of ancient Egypt. London: Cornell University Press

Besculides, A. \& Lee, M., \& Mc Cormick, P. J. (2002). Residents' perceptions of the cultural benefits of tourism. Annals of Tourism Research, 29, 303-319.

Bremmer, J. M. (2008). Greek religion and culture, the Bible and the ancient near east. Leiden, the Netherlands.

Brier, B. (1999). The history of ancient Egypt. The great courses. Virginia.

Brockett, O. G., \& Franklin, J. H. (2003). History of the theatre. Ninth edition, International edition. Boston: Allyn and Bacon. Boston.

Cartledge, P. (2003). Spartan reflections. Berkeley: University of California Press.

Dillon, M. (2002). Girls and women in classical Greek religion. London: Routledge.

Dimou, M. (2016). Delphic celebrations 1927-1930. Patra: EAP.

Falassi, Al. (1987). Festival: Definition and morphology. In: Al. Falassi, Time out of time: Essays on the festival. Albuquerque: University of New Mexico.

Getz, D., Anderson, T., \& Larson, M. (2007). Festival stakeholder roles. Concepts and case studies. Event Management, $10(2), 103-122$.

Gkagka, A. (2018). Festival, its contribution to the local community and its educational role. The case of the International Petra Festival. Patra: EAP.

Kennedy, G. (1972). The art of rhetoric in the Roman world, 30o B.C. - A.D. 30o. A history of rhetoric. Princeton: Princeton University Press.

Long, P. T., \& Perdue, R. (1990). The economic impact of rural festivals and special events: Assessing the special distribution of expenditures. Journal of Travel Research, 2(4), 10-14.

Miller, S. G. (1989). Nemea. A guide to the site and museum. Berkeley: University of California Press.

Orrieux, C., \& Schmitt, P. P. (1995). Histoire Greque. Paris: Presses Universitaires de France.

Parker, R. (2011). On Greek religion. Cornell University Press. New York.

Wilkinson, R. H. (2000). The complete temples of ancient Egypt. New York: Thames \& Hudson. 
I.-S. Kotsori - Ancient Festivals and Their Cultural Contribution to Society

C O A $\mathrm{s}$ 